\title{
演技スキル表現系について \\ On Performance Skill Representation Framework
}

\author{
古川康一慶應義塾大学大学院政策・メディア研究科 \\ FURUKAWA Koichi Graduate School of Media and Governance, Keio University \\ furukawa@sfc.keio.ac.jp, http://bruch.sfc.keio.ac.jp/ \\ 清水 聡史
SHIMIZU Satoshi \\ 吉永 早織 \\ YOSHINAGA Saori \\ 慶應義塾大学環境情報学部 \\ Faculty of Environmental Information, Keio University \\ t02485ss@sfc.keio.ac.jp \\ (同上) \\ t02007sy@sfc.keio.ac.jp
}

keywords: skill science, performance skill, skill representation, performance rule, dynamic integrity constraint

\section{Summary}

In this paper, we propose a framework for representing performance skill. Firstly, we notice the importance of performance skill representation. We introduce five different representation targets: performance tasks, performance rules, pre-shaping actions, dynamic integrity constraints, and performance states. Performance task description consists of a sequence of performance tasks and expressions. It acts as a goal description in planning. Performance rules describe model performance methods for given tasks including how to shape body parts and how to use various muscles. Pre-shaping action rules are similar to performance rules. Its role is to pre-shape in between consecutive tasks to prepare for the next task. Dynamic integrity constraints specify constraints to be satisfied during performance. They provide such general rules as prohibiting simultaneous strong activations of agonist and antagonist. Performance states are for describing real performance done by players including professionals and amateurs. The aim of the framework is to provide a uniform scheme for representing model performance methods given performance score such as music score. The representation framework will define targets of inducing formal skill rules as well as describing performance states automatically from biomechanical performance data. It also is related to a fundamental research issue of attributes finding/selection in discovering useful rules for skillful performance. We conclude our paper by stating future research direction.

\section{1.は じめ に}

身体知の解明は，困難な課題である．従来は，スポー ツ科学の分野を中心に種目ごとに多樣なアプローチが採 られてきた．しかしながら，光れらの努力が 1 つの方向 に収束しているようには見られない，关の理由は，身体 知自身の複杂倠性，および進化性にあると考えられる．第 1 の問題は, 人工知能の分野で，いわゆる不良設定問題 と呼ばれている困難性であると考えられる．弚れは，文 脈依存性と言い換えても良い. 第 2 の問題は, スキル自 身が発展を続けている，という問題である．㫕れは，高 度な熟達者による新たな着想に基づく，新たなスキルの 発見の可能性である. 我々は, この 2 つの問題に取り組 み, 5 年以内での問題解決・実用化を目指して, 近未来 チャレンジセッション「身体知の解明に向けて」を発足 させた [古川 03] .

この二つの問題へのアプローチとして取り組まなけれ ばならない課題には, 演技スキルの知識表現系の設計，
しなやかな動きをモデル化するために必要な粘弾性力学 モデルの構築，スキル解明の着眼点を得るための属性発 見・選択，スキルの個人差のモデル化などが考えられる. 本稿では, 兴の中でとくに第 1 の課題である演技スキル の知識表現系の設計を取り上げる．本論文では，とくに チェロの右腕による運弓動作に着目して , 光のスキルの 表現を目的として，演技スキル表現系を提案するが，こ こでの提案は, ダンスやスポーツなどでのスキルの表現 にも応用が可能であると考えられる．

本稿の構成は, 以下の通りである . 2 章では, 本チャ レンジのゴール, 研究計画, および進捗状況について述 ベる．また，本論文に取り上げる演技スキルの表現系の， 本チャレンジでの位置づけについて述べる . 3 章では , こ れまでの演技表現の試みについてサーベイする .4 章で は, 演技スキルの知識表現の枠組みを与える . 5 章から 9 章では，4 章で与えた演技スキルの知識表現の各構成要 素について，光れらの詳細を述べる．5 章では，演技譜の 表現について概説する．6 章では, 演技譜を構成する各 
演技課題に対する演技ルールの表現を与える .7 章では， 調節動作の表現について述べる .これは, pre-shaping と 呼ばれる, 各演技課題のための準備動作である.8 章で は，演技中に満たされなければならない動作一貫性制約 条件について述べる.9 章では, 演技状態系列の記述を 行う．演技状態は，実際の演技者による演技のされ方を 記述するものである. 10 章では， 5 章から 9 章で与えた 各演技表現の構成要素をどのようにして作り上げていく のか, 弚の過程について述べる.11章では，本演技スキ ル表現系を利用した演技のプラニングについての構想を 述べる. 12 章では, 演技スキル表現系の開発に向けての 今後の課題を述べると共に, 身体知の解明に向けた本近 未来チャレンジのゴールの達成の可能性について論じる．

\section{2. 本近未来チャレンジのゴールと研究計画に ついて}

我々が提案した近未来 $\mathrm{AI}$ チャレンジのテーマ「身体 知の解明に向けて」のゴールは，身体知の解明のための 方法論の確立である.身体知の対象には，楽譜通りの演 奏のような安定した環境を仮定したクローズドスキルと， 試合において相手に合わせた動きをするような不安定な 環境でのオープンスキルの2 種類があるが [Poulton 57]， ここではより基本的で訓練段階においても先行して獲得 されるクローズドスキルを取り上げる . 具体例として取 り上げるチェロの運弓動作は, クローズドスキルの要素 が強く，また，弚れ自身は高度なスキルを要求するので， ここでの研究対象としてふさわしいものと考えられる.

本提案の特徵は, 従来力点が置かれてきた運動学に止 まらず，運動力学をも考慮した樣々な技巧的な動きの原 理の解明に焦点を当てている点である，弚のためには，結 果としての体の動きのみに注意を払うのではなく，乥の 原因となる，筋肉の使い方，姿勢のとり方を問題にしな ければならない，また，本研究テーマを遂行するに当た り，いくつかの課題を設定した . 第 1 の課題は, 動作一 貫性制約条件，すなわち，複数の筋肉の活動，姿勢のと り方，あるいは協調動作などに関する制約条件を明らか にすることである．弚れらの制約条件は，好ましい体の 動きを選択する際の探索空間の絞込みを可能とする．第 2 の課題は，スキルを的確に表現するのに必要となる属 性発見・選択の問題である.第 3 の課題は, 従来の剛体 力学モデルから脱却して，しなやかさを扱うのにより適 した, 粘弾性力学モデルの構築である. 第 4 の課題は, データマイニングなどの方法による観測データからのス キルの自動抽出手法の開発である .

我々は, これらの各課題について, 樣々な研究活動を 続けてきた.第 1 の課題，すなわち，動作一貫性制約の解 明に関しては, 兴の重要性を [Ueno 00] で指摘した . 第 2 の課題，すなわち，属性発見・選択については, [古川 05b] で炎のアプローチを解説した . 第 3 の粘弾性力学モ
デルの構築に関しては, とくに鞭運動についての考察を 行い, 弚の成果を [Furukawa 05] で報告した. 第 4 の課 題，すなわちデータマイニング手法によるスキルの自動 獲得については, 光の研究開発の一端は [植野 05] で発 表した。

本論文で提案する演技スキルの知識表現系は，これら の各アプローチの統合プラットフォームと位置づけるこ とが出来る. 光のため, 演技スキルの知識表現系の研究 開発は, 本近未来 AI チャレンジの中では, 全体の統合 計画として捉えることが出来る.また, 本知識表現系自 身としても，与えられた課題に対する適切な動作系列の プラニングのために直接利用することを目指している .

本論文では, クローズドスキルの例としてチェロの運 弓動作を取り上げ，兴のスキルの記述を表現するための 演技スキル表現系を提案するが, 弚れは単にチェ口の運 弓動作の表現に止まらず，より多くの対象に対して応用 が可能であると考えている .

\section{3. 演技表現の関連研究}

演技譜とは，音楽や舞踊などの演奏や演技などのための プログラムであり, 最もよく知られているのは音楽の演奏 のための楽譜である .ところで, 演技スキルは, 体の動き が重要である.光のため, 体を動かす舞踊の表現は, 演技 スキルの表現により深く関係しており，舞踊の表現として は, Labanotation がよく知られている. Labanotation とはルドルフ・ラバンか開発した舞踊を記録する記譜法 の一種であり，国際会議でしばしば改良が行われ，欧米 において舞踊研究や教育の分野で幅広く用いられている [中村 01a] . 音楽におけるスコア譜と考え方は近く，スコ ア譜がオーケストラの各パートの音の情報を時系列的に 書き記せるのに対し, Labanotation は身体の各部位の 状態を時系列的に記号として表現できる . Labanotation は選択された静止点での各身体部位の空間上の位置を提 示するにとどまり，ある型から別の型へ移行する際の軌 跡については記述を行わない，弚れによって，記述量の 爆発を防いでいる．また，楽譜における表情記号 (クレッ シェンド，フォルテなど) に当たるものも存在する．

我々が目指すところと Labanotation は関係性か強い が，いくつか注意すべき点がある．第 1 に，舞踊譜を理 解するためにはスコア譜を読みこなすのと同じように， それれりの訓練が必要であるということであり，第 $2 に ，$ 本論文で提案する演技スキル表現系は筋肉の活動状態を 含んだ運動力学を考慮しているが, Labanotation は運 動学的な側面しか記述できないということである.さら に，第 3 にダンスは型兴のものが半ばゴールであるが， 音楽演奏においては关の結果として現れる音が良くなけ ればならないという点も我々の問題と異なる.この点に ついて補足すれば, 演奏においては楽器に制約されたア プローチを求められ，個人差の問題が舞踊よりも顕著に 
なることは自明であるとも言えよう . このような問題点 は大きいが，近年 Labanotation とコンピュータをリン クさせた研究が始まっており，運動学的な側面を補う意 味で参考になる部分があり，本節て諸研究の一部を紹介 したいと考える．

まず，高木ら [高木 96] による研究では, IntelligentPad[IPC 05] 上に Labanotation を構築し，CG で人間 の動作を製作する際の手間を削減させている . 吉田ら [吉 田 98] は，Labanotation の譜面をコンピュータに読み 込ませる LabanReader を開発し，GUI て編集のできる Laban Editor の開発も行っている. 弚して㚇れらととも にモーションキャプチャを利用した Labanotation の学習 システムを開発し, 複雑な Labanotation の理解を助け ることを試みている [中村 01b] ．八村ら [八村 01] はモ一 ションキャプチャから得られたデータを Labanotationの 舞踊譜に変換する手法について模索している.中澤ら [中 澤 04] はモーションデータから速度の極小值に注目した 最小セグメント化に EM-Algorithm を使用し，より大き な単位にするために Apriori Algorithm を適用させ , 生 体データをLabanotation 化する精度をさらに上げる手 法を提案している.[Zhao 04] では, Labanotaion の専 門家によって訓練されたニューラルコンピューティング モデルを用いて，モーションキャプチャとビデオデータ から得られた手の動作の特徵抽出についての研究を行っ ている。

上述した研究は必ずしも演技スキル表現系に直接結び つくとは限らないが, 舞踊の世界で数十年批評され改良 されてきた Labanotation がコンピュータと親和性が高 く，身体運動を表現する記号の新たな活路を見出すことに 成功していると言える，光れを音楽における身体動作研 究に応用するのは, 弚う難しいことではないと思われる。

Labanotation と本研究での表現の最も異なる点は, 乥 の抽象度である . 本稿で与える演技の表現は，体の具体 的な動き光のものではなく，スキルという観点から見て 重要であると思われる「演技課題」を単位として，弚の 記述を行うことを狙っている，乥れは，実際の動き自身 を記述するのに比べ，より抽象的である.また同時に，光 の時の体の各部分の使い方を記述している点では, より 詳細である。

演技スキルは, 動きが本質的である. 产のため, 知識 表現自身，静的な論理表現の枠を超えなければならない， そのような表現としては，Event Calculusに基く発想 論理プログラミング (Abductive Logic Programming, ALP)[Kakas 93, Kakas 98] , Situation Calculus に基 くアクション言語 [Gelfond 93, Inoue 05] などが兴の候 補と考えられる.これらの表現系は時間経過に伴って変 化する世界の記述を可能としているので，弚れらを用い ることによって, 動きに関するさまざまな推論が可能と なる.本稿では, 演技の各瞬間を表現する言語として静的 な命題論理を考え，演技の変化を捉える表現言語として，
それらの時系列を考える．これは，ALPやアクション言 語への翻訳が可能であり，光れらの表現系が持つ推論能 力を兴のまま利用することが可能であると考えられる．

\section{4. 演技スキルの知識表現の枠組み}

演技スキル表現の構成要素としては，1. 演技者が演ず べき事柄を表現する演技譜，2. 規範的な演技方法を表現 する演技ルールの表現，3. 各演技課題の遂行にとって最 適なポジションを作るための調節動作，4. 演技中に満た されなければならない動作一貫性制約条件の表現，およ び5. 実際の演技状態系列の表現，の 5 種類が考えられる .

第 1 の演技譜は, ダンスや楽器演奏などでの一連の演 技を表現する演技課題と表情の対の系列によって与えら れる.この系列は，プラニングにおけるゴールに相当す るが, 通常のプラニングと異なる点は, 弚れが時系列に なっている点である

第 2 の演技ルールは, 各演技課題を遂行するための規 範的な演技方法を与える . 各演技ルールは , 各課題の説 明 (課題名)，各課題を遂行するために必要な体のポジ ション (前提条件)，乥の課題の遂行によってもたらさ れる表情上の効果，およひ課題の遂行に伴う副作用（体 のポジションの状態変化）によって構成される．

第 3 の調節動作は, pre-shaping とも呼ばれ，各課題 の遂行に適した体のポジションを作るための動作である . これは準備動作であるが，実際には課題の遂行と並行し て行われることが多い、調節動作は, 調節動作の説明 (調 節動作名），各調節動作を遂行するために必要な体のポ ジション (前提条件)，および光の遂行に伴う副作用（体 のポジションの状態変化) によって構成される.

第 4 の動作一貫性制約条件は，演技中に満たされなけ ればならない制約条件を与える，一貫性制約条件は，デー タベースの用語であり，データベースが全体として満た していなければならない(あるいは違反してはならない) 条件を指している.ここでは，弚れを動作の記述に導入 した .とくに，筋肉レベルでの体の使い方の不整合を防 ぐことを目的として，この記述が利用される。たとえば， 上腕二頭筋は肘を曲げるための筋肉であるが，上腕三頭

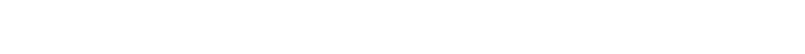
肉を同時に強く活性化させると, 时関節か動かなくなっ てしまう.このような状況が起こるのを禁止するための ルールが動作一貫性制約条件である.

第 5 の演技状態系列は，実際の演技者による演技のさ れ方を記述するものである．演技状態の記述は，実際に は演技ビデオの観測や演技中の生体力学的な計測データ などから得られるもので, 実際の演技が規範的な演技と どう違うのかを知るのに有用な情報を提供する .すなわ ち，演技状態系列は，実際の演技の抽象表現と見なすこ とが出来る.

これら 5 つが演技スキル表現系を形成している. 弚れ 
表 1 演技スキル表現系の構成

\begin{tabular}{|c||l|}
\hline 演技スキル表現系の構成要素 & 各構成要素の内容 \\
\hline \hline 演技譜 & (演技課題 + 表情) 系列 \\
\hline & 課題名 \\
演技ルール & 前提条件 \\
& 表情上の効果 \\
& 身体状態の変化 \\
\hline & 調節動作名 \\
& 前提条件 \\
調節動作 & 身体状態の変化 \\
& 満たすべき身体状態 \\
\hline 動作一貫性制約条件 & 身体状態の変化の列 \\
\hline 演技状態系列
\end{tabular}

を図示すると，表1のようになる．

\section{5. 演技譜の表現}

演技譜は，すでに述べたように，舞踊や楽器演奏など での一連の演技を表現する演技課題と表情要求の対の系 列によって与えられる. 光して，弚れらは，プラニングに おける一連のゴールを定める .この系列の構成要素，す なわち, 各演技課題および表情要求は, 楽器演奏や舞踊, ゴルフスイングなどの各種目ごとに光の種別を決めなけ ればならない .

演技を定性的に捉えると，ある時刻て瞬間的に発生する 瞬時課題とある時間区間継続する連続課題に区別される． これらは光れ光れ，定性プロセスモデル [Forbus 84, 㴊 93]における事象とエピソードに対応している．定性推 論での定式化との違いは, 我々のアプローチは, 楽譜や 舞踊の振り付けのような指定されたパフォーマンス系列 をターゲットとして与え，光れを達成するためのプロセ ス (動作) や装置 (人体) の制御列を生成しなければなら ない点である。

チェロの運弓動作を例に取ると, 瞬間課題は, 弓の返 し, 弓の停止, 弓の弦への接触と離反, 移弦が挙げられ る.また，連続課題としては，下げ弓，あるいは上げ弓 による音の連続生成がある、瞬間課題と連続課題は，交 互に発生するものと考えられる .

弚れらの各課題の種別は，たとえば弓の返しでは，下 げ弓から上げ弓への返しと关の逆がある．また，光れ光 れが弓のどこで起こるのかによって，さらに課題の細分 化がなされる．このように，一つ一つの課題を細分化し たものを表 2 に示す .

この表から分かるように, 運弓動作だけでも，弚の可 能な課題の数は, 瞬間課題では, 弓の返し・弓の停止の 6 パターンおよび離弦・接弦の 2 パターンが移弦の 5 パ ターンと組み合わさるので, 合計 60 通りあり, 連続課題 では, 弓の速度から発音までの各課題の組み合わせ数の
表 2 チェロの運弓動作における演技課題

\begin{tabular}{|c||l|}
\hline \multicolumn{2}{|c|}{ 瞬間課題 } \\
\hline \hline \multirow{3}{*}{ 弓の返し $\dagger$} & 弓先 \\
& 弓中央 \\
& 弓元 \\
\hline \multirow{3}{*}{ 弓の停止 $\dagger$} & 弓先 \\
& 弓中央 \\
& 弓元 \\
\hline 離弦・接弦 & - \\
\hline & 同行 \\
& 隣弦上行 \\
移弦 & 隣弦下行 \\
& 離弦上行 \\
& 離弦下行 \\
\hline
\end{tabular}

†は互いに排反.

\begin{tabular}{|c||l|}
\hline \multicolumn{2}{|c|}{ 連続課題 } \\
\hline \hline \multirow{2}{*}{ 弓の速度 } & 高速 \\
& 低速 \\
\hline & 単音 \\
& 引つ掛け \\
& 二重音 \\
音型 & 多重音 \\
& アルペジョ \\
& 上下繰り返し \\
& 下上繰り返し \\
\hline \multirow{2}{*}{ 弓使い } & 下げ弓 \\
& 上げ弓 \\
\hline \multirow{3}{*}{ 発音 } & レガート \\
& スタッカート \\
& スピッカート \\
\hline
\end{tabular}

84 通りある .

演技譜の要素の第 2 の成分である表情要求は, 楽器の 演奏の場合には譜面に書かれた表情記号に対応する .こ の表情要求は, 音符の動きを楽譜通りに忠実に演奏する だけでなく，乥こに書いてある表情記号を守りながら演 奏することを要求している．表情も，事象と同樣，瞬時 表情と連続表情とがある .たとえば, スフォルツァンド は前者の例で, クレッシェンド, デクレッシェンドなどは 後者の例である.また，楽譜上の表情記号の他にも，速 いパッセージでは正確性を要求し, 遅いパッセージでは 柔らかさを要求することが多いが, これらの要求も表情 要求の一種と考えられる .

プラニングで言えば，演技課題は達成すべき課題の論 理的側面を表し，表情要求は美的側面を表している.

図 1 , 図 2 に, 演技譜の具体例を示す.図 1 は, 対象と なる運弓記号つきの楽譜 (ボッケリーニのロンドの冒頭) であり，図 2 は，対応する演技譜を表す． 


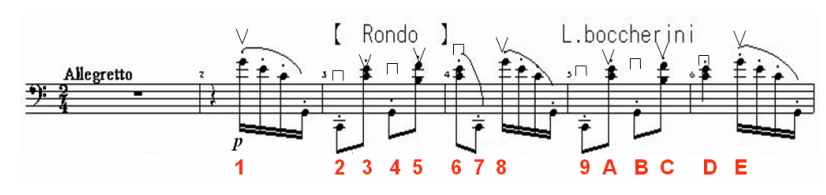

図 1 楽譜

[1(高速上げ弓下降アルペジョスラースタッカート，p)， 弓元弓返し, $[2,4$ 高速単音下げ弓スタッカート, 弓中央 離弦上行移弦弓返し，3,5 高速重音上げ弓スタッカート] $\times 2$, 弓元弓返し， 6 高速重音下げ弓弓元スタッカー 卜, 弓中央離弦下行移弦弓同行, 7 高速単音下げ弓弓中 央スタッカート, 弓中央離弦上行移弦弓返し, 8 高速上 げ弓下降アルペジョスラースタッカート，弓元弓返し， [9,B 高速単音下げ弓スタッカート, 離弦上行移弦弓返 し, $\mathrm{A}, \mathrm{C}$ 高速重音上げ弓スタッカート] $\times 2$, 弓元弓返 し, $\mathrm{D}$ 高速重音下げ弓スタッカート，弓中央弓返し， $\mathrm{E}$ 高速上げ弓下降アルペジョスラースタッカート， $\cdots$

図 2 対応する演技譜の例 . 表情要求が与えられていない場合時に は演技課題のみが書かれている .

\section{6. 演技ルールの表現}

各演技課題に対して，乥れを実現するための演技ルー ルが複数存在する. 各演技ルールは, 各課題の説明 (課 題名）, 各課題を遂行するために必要な体のポジション (前提条件)，弚の課題の遂行によってもたらされる表情 上の効果 (結果表情)，およひ課題の遂行に伴う体のポ ジションの状態変化 (副作用) によって構成される．演 技ルールは，プラニングにおけるオペレータに相当して いる. 谷の形式を以下のように定める.

【定義 1】（演技ルールの形式）演技ルールは，以下の 形式を持つ：

op (task: <課題名 $>$, result_expr:<結果表情 $>$, body_cond: $<$ 前提条件 $>$, side_effect: $<$ 副作用 $>$ )

ここで，<課題名〉は，課題の種別を表す名前であり， 各課題を特徵付けるパラメータの並びで表現する．＜結 果表情>は，弚の課題を遂行することによってもたらさ れる表情上の効果である.<前提条件>は，弚の課題を 遂行するのに必要な体の状態の記述である . <副作用> は，光の課題を遂行したことによってもたらされる体の 状態の変化である.

課題名の例には,「中速単音下げ弓弓元」「高速上下繰り 返し下げ弓弓元」などがある . 後者の課題は , 弓元から 弓を 2 弦に跨って高速に繰り返し振動させるように演奏 する課題を表す . 各課題を達成するのに適した身体各部 の活性度などの条件を与えるのが，<前提条件>である． 弚れらの条件は, 命題論理のリテラルの連言によって記
述される．ここに現れる命題記号は，身体の生体力学的 な状態を表現するアトムであり, 生体力学的アトムと名 付ける. 乥れらは, 各筋肉の活性状態, 関節の硬軟, 姿 勢の伸び縮みなどを表す．たとえば，「高速上下繰り返し 下げ弓弓元」の条件は，以下のように記述される：

体縮み $\wedge$ 肩固定 $\wedge$ 上腕筋中活性化 $\wedge$ 手首先指後

また,「同行弓先弓返し」の条件は, 以下のように複数 存在する :

体伸び $\wedge$ 肩固定 $\wedge$ 腰筋活性化 $\wedge$ 大腿筋高活性 化 $\wedge$ 肘先手首後 $(1)$

体伸び $\wedge$ 肩やや柔軟 $\wedge$ 肘固定 $\wedge$ 上腕筋中活性 化 $\wedge$ 手首先指後 $(2)$

ここで, 前者の連言は腰と肩を使った奏法に対応し， 後者は上腕筋による奏法を表す .このような複数の条件 が存在する場合 , 各条件ごとに個別の演技ルールを定義 する。

つぎに, 同じくチェロの演奏を例に，<結果表情>に ついて考える.<結果表情>は，与えられた前提条件の 下での課題の遂行によってもたらされる表情を表す．上 の例で, (1) の弾き方は腰と肩を使っているので, 音が しつかりしているが，柔軟性に欠ける，乥のため，表情 は「力強い」,「音が大きい」などとなる .一方,$(2)$ の弾 き方は上腕と手首を使っているので, 柔軟性に富み，し かも反応が速い，弚のため，表情は「切れが良い」,「正 確である」などとなる.このように，1つの課題名に対 して, 複数のルールが存在する可能性があるが, 弚れは 期待される表情を満足するために必要になる.

4 番目の引数であるく副作用 $>$ は, 当該課題を遂行した ときにもたらされる生体力学的，あるいは体のポジショ ンの変化を示す. 产の形式は, <前提条件 >の形式と同 じである . この引数は, プラニングでの「オペレータの 効果」に相当する．以下に，演技ルールの具体例を示す． この例は, チェロの運弓課題「同行弓先弓返し」に対す る二通りの演技ルールを示している .

ルール例 1: 腰と肩を使って弓を返す奏法

$o p($ task:同行弓先弓返し, result_expr:力強い, body_cond:体伸び $\wedge$ 肩固定 $\wedge$ 腰筋活性化 $\wedge$ 大 煺筋高活性化 $\wedge$ 肘先手首後, side_effect:)

\section{ルール例 2: 上腕筋を使った手首の返しによる奏法}

op(task:同行弓先弓返し, result_expr:正確, body_cond:体伸び $\wedge$ 肩やや柔軟 $\wedge$ 肘固定 $\wedge$ 上 腕筋中活性化 $\wedge$ 手首先指後, side_effect:)

ここで，<副作用 >が与えられていないときは，<前提 条件>と同じであると仮定した . 前提条件および副作用 
に現れる生体力学的アトムの語彙を選択する問題は, 機 械学習における属性発見・選択問題とみなすことが出来 る、適切な語彙を用いれば，各ルールは課題の演技にとっ て妥当なものとなるであろう．属性発見・選択問題はス キルサイエンスにとっても最も重要な問題であり，メタ 認知 , 時系列データからの知識発見などの樣々な手法が 取られている.詳細については, [古川 05a, 古川 05b] を 参照されたい。

演技課題系列，表情系列とも，楽譜で指示されること が多いので, 通常は乥れらの情報は楽譜から得られると 考えてよい，しかしながら，兴れらは時代によって，あ るいは作曲家によって大きく異なり，一般的には，時代 が遡るにつれて，弚れらの指定は少なくなる傾向がある． また，作曲家による暗黙的な演奏スタイルの存在も知ら れている. 兴のため，これらの情報を楽譜だけから抽出 することは困難である .

上述した演技課題は，ひとつの瞬間課題，あるいはひ とつの連続課題を対象としていたので, 基本演技課題と 呼ぶことにしよう.一方, 実際には, これらの基本課題 を同時並行的に遂行したり，あるいは同じパターンを繰 り返したりすることが良くある．弚のような場合，弚の 同時並行的複数課題, あるいは連続的複数課題を一まと めとして，新たな課題と考えたいことがある．このよう な課題を複合課題と呼心゙ことにする．たとえば，瞬間課 題は，弚れ自身ではあまり意味が無く，弚の前後の連続 課題が与えられて初めて意味を持つと考えられる．たと えば，前後に上下移弦繰り返しがあったときの下げ弓か ら上げ弓の繰り返し，あるいは上げ弓から下げ弓の繰り 返しは, 大変困難な課題として知られている. 光のため, このような典型的な困難な課題を選んで, 光のための演 技ルールを記述することは, 大変意味がある、複合課題 のルールは, 実際には個々の要素である基本課題の記述 を合成して得られる.このとき，<前提条件 $>$ は, 要素課 題の前提条件をすべてへで結合しなければならない．し かしながら，この組み合せは常に上手くいくとは限らな い、乥れは，後で述べる「一貫性制約条件」を満たさな ければならないからである。

\section{7. 調節動作の表現}

調節動作は，演技課題系列を演技ルールの系列で遂行 できれば不要である．しかしながら，ある演技課題から 次の演技課題に移るときに, 前者に対応する演技課題の 副作用が後者の演技課題の遂行を邪魔する場合，すなわ ち，対応するすべての演技ルールの前提条件が产の副作 用を満たさないとき，弚の演技課題は遂行できなくなっ てしまう．この問題を解決するのが，調節動作である．

調節動作の構成要素は, 調節動作の説明 (調節動作名), 各調節動作を遂行するために必要な体のポジション (前 提条件)，および关の遂行に伴う体のポジションの状態変
化 (副作用)の3つである .これは, 演技ルールの構成 要素から「結果表情」を除いたものである .ルールの表 現形式は，定義 1 に準ずる。

調節動作の具体的な例としては, 弓先での下げ弓から 上げ弓への弓の返しのときに,「手首先指後」の状態を作 らなければならない，という状況か泩じる．このとき，下 げ弓の実行中に「指伸ばし」の調節動作をしなければな らない、しかしながら，この調節動作自身が，光の動作 を実行するための<前提条件>があるので, 光れが同時 に実行している演技課題の遂行の<前提条件>，あるい は<副作用 $>$ に違反してはならない，という厄介な問題 が生じる．すなわち, 演技のための最適な方法を探すた めには, 関連する前後の演技, および, 調節課題の実行 の可能性も考えて決める必要がある .

調節動作に関連して，興味のある体のポジションにニ ユートラルポジションがある .これは, あるビオラ奏者 による提案であるが, 楽譜上にニュートラルポジション を取るべき場所を決めておき，弚こでとのポジションを 取るようにする.ニュートラルポジションはリラックス して，しかも体の伸びた状態であり，兴の状態から他の どんな状態への移行もがスムーズに行えるのが兴の特徵 である．もし，ニュートラル状態を取るべき場所が決ま れば，上に述べたようなプラニングでの矛盾の回避の問 題も, 弚のプランを作る課題列が短くなり, 問題の解決 が容易になる。

表 3 に , チェロ演奏の場合の調節動作の一覧を示す．

\section{8. 動作一貫性制約条件の表現}

植野等 [Ueno 00] は, スキルの達成のためには, 動作 に関する動作一貫性制約条件を満たさなければならない ことを指摘した 、一貫性制約条件は，もともとデータベー スにおいて定義された概念であり, データベース中のす べてのデータが満たすべき条件のことを指している．植 野等は，弚の概念をスキルのドメインに応用した．動作 一貫性制約条件違反は，複合課題で起きる事もあれば， 継続した課題同士の組み合わせで起きる事もある. 複合 課題での動作一貫性制約条件は, 兴の構成要素である異 なった基本課題に含まれるリテラル間での制約条件違反 を表現する .たとえば, 高速移弦の課題は, 产のルール の前提条件で上腕筋でのインピーダンスを弱くすること を要求しているが, もし弓の返しの課題が同時に存在し たなら，乥こでは上腕筋のインピーダンスを強めにしな ければならないとすると，この2つの課題は，お互いに 制約条件違反を起こすことになる．これは，主働筋と拮 抗筋の強い共起が弚の原因となる。また, 制約条件違反 は腰筋と指筋のように, 遠く離れた筋肉同士の間にも発 生する.たとえば, 課題が指の柔軟な状態を要求してい る場合に，腰筋によって連動して指筋が活性化してしま う場合，このような制約条件違反が発生する.このよう 
表 3 チェロの運弓動作における調節動作

\begin{tabular}{|c|c|c|c|}
\hline & ゴール & 前提条件 & 副作用 \\
\hline $\begin{array}{l}\text { 体幹の } \\
\text { 伸ばし }\end{array}$ & $\begin{array}{l}\text { 体幹の伸縮 } \\
\text { 状態を伸ば } \\
\text { し状態にす } \\
\text { る }\end{array}$ & $\begin{array}{l}\text { 背笳のイン } \\
\text { ピーダンス } \\
\text { が過度に強 } \\
\text { くはない }\end{array}$ & $\begin{array}{l}\text { 背筋のイン } \\
\text { ピーダンス } \\
\text { が強まる }\end{array}$ \\
\hline $\begin{array}{l}\text { 体幹の } \\
\text { 縮め }\end{array}$ & $\begin{array}{l}\text { 体幹の伸縮 } \\
\text { 状態を縮め } \\
\text { 状態にする }\end{array}$ & $\begin{array}{l}\text { 背筋のイン } \\
\text { ピーダンス } \\
\text { が過度に強 } \\
\text { くはない }\end{array}$ & $\begin{array}{l}\text { 背筋のイン } \\
\text { ピーダンス } \\
\text { が弱まる }\end{array}$ \\
\hline $\begin{array}{l}\text { 指の伸 } \\
\text { ばし }\end{array}$ & $\begin{array}{l}\text { 指を伸ばし } \\
\text { て手首前指 } \\
\text { 後の状態を } \\
\text { 作る }\end{array}$ & $\begin{array}{l}\text { 前腕のイン } \\
\text { ピーダンス } \\
\text { が過度に強 } \\
\text { くはない }\end{array}$ & $\begin{array}{l}\text { 前腕のイン } \\
\text { ピーダンス } \\
\text { が強まる }\end{array}$ \\
\hline $\begin{array}{l}\text { 左の背 } \\
\text { 筋の弛 } \\
\text { 緩 }\end{array}$ & $\begin{array}{l}\text { 左の背筋の } \\
\text { 過度な緊張 } \\
\text { をほぐし，} \\
\text { 左手のポジ } \\
\text { ション移動 } \\
\text { に備える }\end{array}$ & $\begin{array}{l}\text { 右背筋のイ } \\
\text { ンピーダン } \\
\text { スが過度に } \\
\text { 強くない }\end{array}$ & $\begin{array}{l}\text { 右背筋のイ } \\
\text { ンピーダン } \\
\text { スが強まる }\end{array}$ \\
\hline $\begin{array}{l}\text { 重心の } \\
\text { 移動 }\end{array}$ & $\begin{array}{l}\text { 弓の返しょ } \\
\text { り早い位相 } \\
\text { で重心を移 } \\
\text { 動させる } \\
\text { これによっ } \\
\text { て, 重心の } \\
\text { 動きで弓を } \\
\text { 引っ張る }\end{array}$ & $\begin{array}{l}\text { 動かす方向 } \\
\text { の足を突っ } \\
\text { 張らない }\end{array}$ & $\begin{array}{l}\text { 逆足のイン } \\
\text { ピーダンス } \\
\text { か強まる }\end{array}$ \\
\hline
\end{tabular}

な離れた筋肉同士の共活性化は, 体のバランスを取るな どの理由によって発生することがある．また，同時刻で はないが, 継続して発生する課題間の遷移の過程で, 制 約条件違反を起こすことがある .

制約条件には，上に述べた筋肉の活性箇所に関するも のの他に , インピーダンス調節に関するもの, 姿勢に関 するもの，弓の軌跡に関するもの，および時間制約があ る . 各個人で, どのような不必要な筋肉間の共活性化が 起こるかを知ることは, 光の人の悪い演奏の原因を探る 意味で重要である。

動作一貫性制約条件の表現には,ヘッド部を持たない ホーン節を用いる．この表現は，乥のルールの前提部の 生体力学的アトムが同時に成り立ってはならないことを 示す .たとえば，上腕二頭筋と上腕三頭筋の同時高活性 化を制約するためのルールは，

\section{$\leftarrow$ 上腕二頭筋高活性化 $\wedge$ 上腕三頭筋高活性化}

のように表される .

動作一貫性制約条件の中には，必ず満たさなければな らない制約条件と，満たしたほうか望ましい制約条件と
が存在する．たとえば，上記のような筋肉の使用に関す る不整合は起きてはならないが，弚れらが時間的にずれ があり，調節動作によって回避できる場合には，必ずし も満たす必要なない，また，表情要求を満たさないよう な演技法を選う湯合，他に選択の余地がない場合には， そのような制約条件は，無視してよい，前者の制約条件 を強制約条件と呼び，後者を弱制約条件と呼ぶ。これら の 2 種類の制約条件を考慮するためには，モデルの選好 を扱える非単調論理の枠組みが必要である . 非単調論理 は，一般には計算量が大きく，現実問題には使えないと考 えられているが, 後述する発想制約論理プログラミング (Abductive Constraint Logic Programming, ACLP) の枠組みは, 多くの問題に対して効率の良い処理系を実 現している [Kakas 00]．我々は，ACLPに基づく処理系 の実現を計画している.

\section{9． 演技状態の表現}

演技課題の表現は，指定された演技を遂行するのに適 した体の動かし方を与える．ところが，初心者がこのよ うな理想的な体の動きが出来るわけではなく，実際の動 きは光れとは異なると予想される．とのような状況に対 処するために，我々は実際の演技の表現として演技状態 列を導入する，演技状態列は，演技状態の系列であり，各 演技状態は演技者による演技のある瞬間あるいは区間で の状態を表す論理表現である．我々は事象を表現するた めに用いた体伸び，肩柔軟，腰筋活性化などの生体力学 的状態を表すリテラルの連言によって演奏状態を表現す る.与えられた演技課題についての事象列に付随する条 件部と対応する演技状態の相違は，各演技者の個人的な 癖や欠陥を表す。

各演技者の各試行に対して，1つの演技状態時系列が 対応する.これらの表現は，演技データを解析して得ら れる.問題は，演技状態時系列データのセグメンテーショ ンと，演技状態集合の抽出である，演技状態は，課題よ りも種類が多いと考えられ，最悪で, 課題に現れるリテ ラルの矛盾しないすべての連言から成る巾集合 (power set）となる . 演技状態時系列は，課題の時系列と比較さ れ，演技者の演技の診断がなされる．

\section{0. 演技スキル表現の生成}

5 章から 9 章にわたって述べてきた演技スキル表現をど のように生成するかが大きな問題である．本章では，各 構成要素について，弚の生成方法を考察する．

演技譜は，たとえば楽器の演奏では，主として楽譜か ら弚れらの情報が得られる. 舞踊の場合， 3 章で紹介し た Labanotation から演技譜を抽出することが可能であ ろう。しかし，弚れだけで不十分な場合には，弚れを補 うのは演技者, あるいは演技指導者の役割である.オー 
ケストラの場合，弚れは指揮者の役割であろう．とくに 表情要求は，指揮者か独自の指示を与えることも多い．

演技ルールに関しては, 熟達者の自己分析からルール を作っていくのが, 第1の方法である . しかし , 演技ルー ルの多樣性を考えると，弚の方法で完全なルールセット を作れる保証はない，第 2 は，熟達者の実際の演技を計 測し，乥の生体力学的時系列データから演技ルールを自 動抽出する，という方法である。

時系列データから演技ルールを自動抽出するためには， いくつかの問題を解決しなければならない．第 1 は，時 系列データのセグメンテーションである．すなわち，時系 列データのどの部分がどの演技課題に対応しているのか の区分けを行わなければならない，高野等 [高野 05] は， ロボットにいくつかの課題を連続して行わせ , 弚の動作 をモーションキャプチャリングシステムで観測し，关の 観測データからセグメンテーションを行う手法を開発し た，弚の手法は，演技譜に従った一般の演技についても， 適用できるものと考えられる．また，演技譜が与えられ ていれば, セグメンテーションの際に, 課題の系列の情 報を利用したより効率の良いアルゴリズムの構築が期待 できる，一方，困難な問題もある．弚れは，複合課題の 扱いである.とくに，複数の課題が同時並行的に行われ る場合, 光のセグメンテーションは新たな手法を必要と すると考えられる .

セグメンテーションで切り出された各部分に対して，主 として運動力学的なデータから，演技ルールを抽出しな ければならない . 产のための特徵抽出を行うアルゴリズ ムとしては, 音声認識における隠れマルコフモデルや , 時 間軸上の伸縮を許したマッチングを行う Dynamic Time Warping(DTW) などが知られているが, 多変量時系列 データに対して光れらのアルゴリズムを適用することは 容易ではない，一方，麻生等 [Asoh 05] は，ダイナミッ クベイジアンネットワークを解くアルゴリズムとして知 られている Particle Filter Algorithm を用いて , 複数の マイクロフォンと画像データから移動話者の場所を推定 する問題を解いている.

ここでは, モーションキャプチャリングデータから得ら れる肩，肘，手首などの種々の回転角および角速度，筋電 計からの各筋肉の活性度, 床反力系からの重心位置など の複数のデータから，現在の演奏状態を推定する問題を 上記のアルゴリズムを用いて解くことが出来ないか，光 の可能性を検討中である .

調節動作の自動抽出は，原理的には演技ルールと同樣， 演技中の生体力学的時系列データからの自動抽出が望ま しいが, 光れは演技ルールと不可分なので，光れ自身を 取り出すことは不可能である。光のため, 調節動作は, 熟 達者の自己分析からあらかじめ与えてしまうのが適切で ある.こうすれば，演技ルールの構築の際に，調節動作 の部分を差し引くことが可能になるであろう .

動作一貫性制約条件の自動抽出は興味のある問題であ
る.これは，熟達者が演技中に守っている制約条件を見出 すことになるが，この問題に対しては，演技データの全 体的な性質を抽出することが必要になる，弚のため，記 述的学習手法が適していると考えられる.また, 複数の 生体力学的アトム間などの満たすべき条件を抽出しなけ ればならないので, とくに Claudien[De Raedt 97]など の記述的帰納論理プログラミングシステムの利用が有効 であると考えられる .

演技状態列の自動抽出は，手法的には演技ルールの自 動抽出とほぼ同じと考えられる . 異なる点は , たとえば 初心者の演技の場合, 弚れは必ずしも演技譜どおり進め られないので, 演技譜の参照には, 工夫を要する .

\section{1. 演技スキル表現系に基くプラニング}

演技スキル表現系は, 直接的な応用としては, 与えられ た演技課題を遂行するための動作系列のプラニングが考 えられる．与えられたゴールを達成するためのプランを 自動的に求めるプラニングの研究は, 古典的な人工知能の 問題である .よく知られている手法には, STRIPS[Fikes 71] がある . ここでのプラニング問題は , 一般的なプラ ニング問題と異なる点がある. 弚れは, 課題自身が複数 の副課題の系列として与えられているので, プラニング 自身，副プラニング問題の系列として定義される．また， ここでは, 各副プラニング問題でのゴールは, 与えられ た課題列に含まれる表情要求によって定義される .さら に, 本演技スキル表現系の構成要素の1つである動作一 貫性制約条件は，プラニングにおいて枝刈りのための情 報として利用することが出来る．与えられた動作一貫性 制約条件を満たさない計画は不適切な計画であり，弚の ような可能性は除去されるべきである .

ここでのプラニングにおいて, 最も困難な問題は,ルー ル集合の完全性の要求, およびルールの前提条件を満たす ための状態記述の完全性への要求である.しかしながら， 弚れらを記述し尽くすのは困難であり，事実上不可能で ある.ルール集合の完全性の問題は, 中々困難な問題であ るが, 我々の提案に含まれる調節動作を強化することによ り，この問題の解決は図れると思われる.一方, 状態記述 の完全性については,近年, この問題に対して, 発想論理 プログラミング (Abductive Logic Programming, ALP) の枠組み [Kakas 93, Kakas 98] を用いた形式化として， 発想プラニング (Abductive Planning) が提唱され，不 完全な状態の記述を不完全な述語 (abducible predicate) を導入した発想推論で補う方法が提案されている。また， 実際にこの枠組みを使ってロボットのプラニングへの応 用なども行われている [Shanahan 98]．ALP，あるいは 乥れを拡張した発想制約論理プログラミング (Abductive Constraint Logic Programming, ACLP)[Kakas 00] は 一貫性制約条件および不完全な述語の扱いが可能であり， 我々の枠組みとの適合性が高い，本研究では, プラニン 
グシステムの検討は今後の課題であるが, 実用化を目指 す観点から，本アプローチの有効性は高い .

\section{2.おわりに}

本稿では，演技譜が与えられているときに光の中に現 れる各演技課題を遂行するのに必要とされるスキルを表 現するための演技スキル表現系を提案した . 本スキル表 現系を与えることにより，従来取り上げられてきたスキ ルに関する樣々な問題が共通言語で表現できるようにな ると考えられる.すなわち, 本表現系は演技スキル研究 のプラットフォームを提供することになる . 乥れらの問 題の例は, 多変量時系列データからのスキルの自動抽出, 属性発見・選択問題，個人差の問題などである.

最後に，本研究の今後の課題について述べる. 第 1 に， ここで提案した表現系の具体化を進める予定である．本 表現系は, 演技スキルの個々の要素と，光れらを利用す る処理系とからなる . 個々の要素は, 対象によって異な るが , チェロの運弓動作だけを取り上げても膨大なもの となると予想されるが，問題を限定して，サブセットを 切り出し, 弚の実現を図る予定である. 取り上げる問題 としては，熟達者によって指摘された，一見簡単なよう に見えて実は厄介な課題を考えている．また，処理系に ついては, ALP に基づくプラニングシステムを中心に光 の開発を進める予定である.

第 2 に，本表現系の基礎になっている命題論理を述語 論理に拡張することを考えている. 弚れは必ずしも命題 論理では記述し切れない問題があるという訳ではないが， たとえば動作一貫性制約条件などの記述を，「主働筋と拮 抗筋の同時強活性を禁じる」といった一般規則での表現 を行いたいからである．また，ALPの利用は，これらの 拡張を許すものである。

第 3 に，本表現系に含めるべき要素として，時間制約 を考えたい，時間制約とは，ある課題なり調節動作なり を遂行するのに要する時間のことであり，実際に高度な スキルになるにしたがって, 弚の役割は重要になってく る．時間制約を除いて，与えられた課題をゆっくりこな しても，弚れは高度なスキルを実現しているとはいい難 い . 音楽の演奏の場合 , 時間制約は演奏する曲のテンポ とも関連してくる.特に困難な課題は，速いテンポの部 分であり，弚の意味でも時間制約は重要である．

第 4 に，本スキル表現系の他分野への応用について考 えたい. 本論文で取り上げたチェロの運弓動作は, 弚の中 にスキルを構成する樣々な要素を含んでいるので, ここ で提案した演技スキル表現系自身，弚の表現できる範囲 は充分広いと考えられる。しかしながら，本論文で提案 している演技スキル表現系は，すでに述べたように，あ らかじめ楽譜や振り付けが与えられているようなクロー ズドスキルを対象としており，たとえばサッカーのよう な, 対応すべき状況か著しく多樣で, 弚の影響か強いオー
プンスキルを充分に表現することは出来ない．また，た とえクローズドスキルであっても，対象が異なれば，光 の対象ごとにスキルを記述する別個の属性を必要とする . また，スポーツを対象とする場合，表情要求が速さ，強 さ，正確さなどに限定されてしまい，プラニングにおけ るゴールの性質が , チェロ演奏のような美的な要素が重 要である場合と大きく異なる，光れらの違いが, 表現系 にどのように影響してくるかを考察するのも，今後の課 題である.

より大きな問題としては, 脳の運動プログラムとの関 係がある．とくに，反射運動は，高度なスキルの実現に 深く関与していると考えられているが，弚れを直接証明 した研究成果は得られていない，光のためには脳神経系 による筋肉の活動制御か㵍題となるが, 現在に至るまで, 光のレベルでの計測技術が確立されていない，一方，脳 の運動モデルの研究, すなわちヒトがどのようにして運 動を行っているのかの解明も進められている . 乥こでの 主要なアプローチは, ニューラルネットワーク，あるい は HMM での最適パラメータの学習問題としての形式化 である.これらの研究のターゲットは, 我々の研究に類 似しており，手法的にも，とくに信号レベルの処理では 共通する点も多い. 光れらの研究と我々の研究の最も異 なる点は, 第 1 に前者が脳神経レベルでのモデル化を目 指しているが, 我々の研究はよりマクロな筋骨格レベル のモデル化を目指している点であり，第 2 に得られたも デルの可読性の差異である . モデル化のレベルの差を考 慮して，我々が目指している筋骨格レベルでの演技スキ ル表現系の下部に，より詳細な脳神経レベルでの表現系 を位置づけることは可能である．しかしながら，兴の 2 つの層の間の関連付けは未知の研究領域に属し, 光の追 求は今後の研究課題である.

我々の目的は，身体知の解明であり，言語化である。光 のため，ニューラルネットワーク，あるいは HMM での 動作のパラメータ表現は, 我々の目的に光ぐわない．し かし，この点においても，最近，これら両者のアプローチ を統合する新たな枠組みが提案されている [Zelezny 05] . 乥れは, 機械学習において, 分類精度と可読性を両立さ せることを目的としており，まずニューラルネットワー クや HMM ，あるいはサポートベクタマシンのように分 類精度は優れてはいるがブラックボックスとして働く分 類器を構築して, 弚の分類器を入力として光れとほぼ等 価な可読性の高い述語論理に基づく分類器を構築する， というものである .このようなアプローチも念頭におい て, 本研究を進めていきたい.

\section{謝 辞}

本論文の執筆に当たり，東京大学大学院情報理工学系 研究科中村研究室の高野渉氏には, 同氏のこ研究につい ての詳細なこ教示を頂いた．また，国立情報学研究所の 佐藤健教授，井上克己教授には，発想プラニングについ 
ての有益な示唆を頂いた .この場をお借りして , 深く感 謝いたします．

\section{$\diamond$ 参 考 文 献 $\diamond$}

[Asoh 05] Asoh, H., Asano, F., Yamamoto, K.: Tracking human speech events using particle filters, Proceedings of 2005 IEEE International Conference on Acoustics, Speech and Signal Processing (ICASSP 2005), II-1153-1156 (2005)

[De Raedt 97] De Raedt, L. and Dehaspe, L.: Clausal discovery, Machine Learning, Vol.26, pp.99-146 (1997)

[Fikes 71] Fikes, R. E. and Nilsson, N. J.: Strips: A new approach to the application of theorem proving to problem solving. Artificial Intelligence, Vol.2, pp.189-208 (1971)

[Forbus 84] Forbus, K.D.: Qualitative Process Theory, Artificial Intelligence, Vol.24, pp.85-168 (1984)

[古川 03] 古川康一, 植野研, 五十嵐創, 森田想平, 尾崎知伸, 玉 川直世 : 身体知の解明を目指して, 第 17 回人工知能学会全国大 会, 3D5-01 (2003)

[古川 05a] 古川康一, 尾崎知伸, 植野研 : 身体知解明へのアプ ローチ, 第 19 回人工知能学会全国大会, 2B1-01 (2005)

[古川 05b] 古川康一, 植野研 : AI とスキルサイエンス, 人工知 能学会誌, Vol.20, No.5, pp.510-517 (2005)

[Furukawa 05] Furukawa, K., Kinjo, K., Shimizu, S., Sawai, K., Yoshinaga, S.: On Modeling Bow Arm Movement in Cello Playing by Whip Motion, Proceedings of the 3rd European Medical and Biological Engineering Conference (EMBEC'05), Prague (2005)

[㴊 93] 㴊一博 (監訳) : 人工知能ハンドブック, 第 4 巻, 共立出 版, pp.439-451 (1993)

[Gelfond 93] Gelfond M. and Lifschitz V.: Representing action and change by logic programs, Journal of Logic Programming, Vol. 17, pp.301-321 (1993)

[Inoue 05] Inoue, K., Bando, H., and Nabeshima, H.: Inducing Calusal Laws by Regular Inference, In Kramer, S., and Pfahringer, B. , Inductive Logic Programming, LNAI 3625, pp.154-171 (2005)

[IPC 05] IPC (IntelligientPad Consortium) : URL http://www.pads.or.jp/ (2005.08.04)

[Kakas 93] Kakas, A. C., Kowalski, R. A., Toni, F., Abductive logic programming. Journal of Logic and Computation, Vol.2, No.6, pp.719-770 (1993)

[Kakas 98] Kakas, A. C., Kowalski, R. A. and Toni, F.: The role of abduction in logic programming. In D. M. Gabbay, C. J. Hogger, and J. A. Robinson, editors, Handbook of Logic in Artificial Intelligence and Logic Programming, Vol. 5, pp. 235-324 (1998)

[Kakas 00] Kakas, A. C., Michael, A. and Mourlas, C.: ACLP: Abductive constraint logic programming. Journal of Logic Programming, Vol.44, pp.129-177 (2000)

[McMillen 03] McMillen T. and Goriely A.: Whip Wave, Physica D: Nonlinear Phenomena, Vol. 184, Issues 1-4 , pp.192-225 (2003)

[中村 01a] 中村美奈子 : 舞踊記譜法一用途, 歴史, 分類 , 光して 応用一, アート・リサーチセンター紀要, Vol.1 (2001)

[中村 01b] 中村美奈子, 山川誠, 八村広三郎 : 舞踊記譜法 Labanotation とモーションキャプチャを用いた舞踊教育のための マルチメディア教材の開発, 情報処理学会研究報告, 人文科学 とコンピュータ 50-5，No.51, pp.33-40 (2001)

[中澤 04] 中澤篤志, 中岡慎一郎, 白鳥貴亮, 工藤俊亮, 池内克史 : モーションキャプチャによる全身運動解析と模倣ロボットー「じょ んがら」節を HRP-1S に踊らせる-, 情報処理学会研究報告, コ ンピュータビジョンとイメージメディア 146-5, No.113 (2004)

[Poulton 57] Poulton, E. C.: On prediction in skilled movements, Psychological Bulletin, Vol. 54, pp.467-478 (1957)

[Shanahan 98] Shanahan, M.: Reinventing Shakey, Working Notes of the 1998 AAAI Fall Symposium on Cognitive Robotics, pp.125-135 (1998)

[高木 96]高木龍也，岡田義広，田中讓：記号による記述を用い
た身体モデルの動作制御, 情報処理学会研究報告, グラフィック スと CAD 81-9, No.77, pp.49-54 (1996)

[高野 05] 高野渉，中村仁彦：統計的相関に基づく動作パターン の分節化手法, 第 19 回人工知能学会全国大会, 3F1-02 (2005)

[Ueno 00] Ueno K., Furukawa K., and Bain M.: Motor Skill as Dynamic Constraint Satisfaction, Electronic Transactions on Artificial Intelligence, Vol. 4, Section B, pp.83-96 (2000)

[植野 05] 植野研, 古川康一: ピークタイミングシナジーによる動 作スキル理解, 人工知能学会論文誌, Vol.20, No.3, pp.237-246 (2005)

[八村 01] 八村広三郎, 中村美奈子 : モーションキャプチャデータ から舞踊譜 Labanotation の生成, 情報処理学会研究報告, コ ンピュータビジョンとイメージメディア 128-14 , No.66 (2001) [吉田 98] 吉田康行, 松岡洋介, 八村広三郎: 舞踊譜 Labanotation に基づく身体運動の処理 譜面読取り LabanReader と譜面エ ディタ LabanEditor, 情報処理学会研究報告, 人文科学とコン ピュータ 38-6, No.51 (1998)

[Zelezny 05] Zelezny F., Tolar J., Lavrac N., Stepankova O.: Relational Subgroup Discovery for Gene Expression Data Mining, Proceedings of the 3rd European Medical and Biological Engineering Conference (EMBEC'05) (2005)

[Zhao 04] Zhao L., Norman I. B. : Acquiring and validating motion qualities from live limb gestures, Graphical Models, Vol.67, pp.1-16 (2004)

〔担当委員 : 阿部 明典〕

2005 年 9 月 18 日 受理

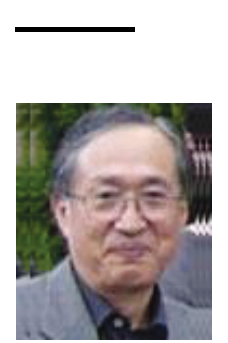

者 紹 介

古川 康一(正会員)

1965 年東京大学工学部計数工学科卒業. 1967 年同大学院 修士課程 (計数工学) 修了. 同年, 電気試験所入所. 1982 年 (財) 新世代コンピュータ技術開発機構へ出向. 1992 年 慶應義塾大学環境情報学部教授, 1994 年より同大学大学 院政策・メディア研究科教授. 工学博士. この間, 人工知 能言語, 論理プログラミング, 帰納論理プログラミング, 暗 黑知の言語化などの研究に従事. 情報処理学会, 日本ソフ トウエア科学会, 日本認知科学会, バイオメカニズム学会,

各会員.

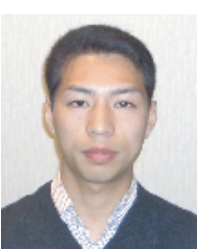

清水 聡史

慶應義塾大学環境情報学部在籍. バイオリン演奏時のスキ ルに興味を持つ. 情報処理学会学生会員

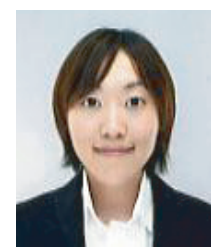

吉永 早織

慶應義塾大学環境情報学部在籍. 組織内における知識共有 に興味を持つ。 